\title{
Teachers' Perception and Challenges of Using ICT in Teaching Mathematics at Secondary Level
}

\author{
Ganesh Prasad Adhikari \\ Tribhuvan University \\ Central Department of Education, Kathmandu, Nepal \\ Email: gpadhikarin@gmail.com
}

\begin{abstract}
The main objectives of this study were to identify the teachers 'perceptions and challenges of using ICT tools in the mathematics classroom at the secondary level in Kathmandu. The major tool of the study was a closed-ended questionnaire consisting of 19 items. The quantitative descriptive survey design was used in this study. The researcher selected 158 teachers by using simple random method from 261 government teachers who teach compulsory mathematics at grade X of Kathmandu district in Nepal. The standardized questionnaire was administered to the sample teachers. The SPSS-25 version database was used to analyze and interpret the collected data. Teachers 'perception of using ICTs in the mathematics classroom was positive with insignificant difference in terms of gender. There were some challenges: lack of knowledge, confidence, enough experience, training, interest and access to ICT tools, lack of technical support, lack of genuine ICT Software and unstable and unreliable internet connection at the schools. Due to these challenges, teachers did not use ICT in the classroom. Therefore teachers should learn more to improve their knowledge and skills in ICT. The government should focus on management strategies and policies to reduce the challenges faced by teachers in mathematics classrooms. By these policies, they can use the ICT tools in the classroom.
\end{abstract}

Keywords: Teachers'Perception, Challenges, ICT in Mathematics Education

\section{Introduction}

The term ICT refers to the forms of Information and Communication Technology (ICT) that are used to communicate, transmit, store, create, share or exchange information. The broad definition of ICT includes technologies such as radio, television, video, telephone (landline and mobile), computer and network hardware and software as well as the tools and services associated with the technology. It is an important part of many organizations these days (Apeanti, 2014). It began to be used in schools in the early 1980s; and several schools suggest that ICT could be an important part of education for the new coming generation (Bransford et al., 2000). It is also the modern concept in the field of mathematics education. ICT makes easy to understand new concepts, knowledge, skills related to 
mathematics educational contents. ICT in mathematics education means teaching and learning of mathematical contents by using ICT. It is integration to the process of using any ICT resource, device or tool to improve the classroom teaching and learning process; and enhance students' teaching of mathematics (Lefebvre et al., 2006). It can also contribute to universal access to education, equity in education, provision of quality education and teaching, professional development of teachers and management, governance and a more effective administration of education.

Nowadays, worldwide research has shown that ICT can lead to improve student learning and better teaching methods (Otemuyiwa \& Attah, 2020). Dawes (2001) stated that new technologies can help maintain education throughout the curriculum and provide opportunities for effective communication between students and teachers in a way that were impossible before. ICTs in education can transform teaching. However, this potential may not be easily realized, as (Dawes, 2001) specified, he said, "problems arise when teachers are supposed to implement changes in what may be a problem circumstances "(p.61). Due to the importance of ICTs in society and in the future of mathematics education, it is necessary to identify integrating these technologies into schools which would be an important step in improving quality teaching and learning. Balanskat et al.(2006) stated that although teachers seem recognized the value of ICTs in educational institutes, they continue to face barriers to adopt these technologies in their teaching and learning.

\section{Teachers' perception of the use of ICT in teaching and learning}

The term 'perceptions' as attitudes, behavior, self-beliefs and/or views that a person has developed toward anything (Boulton, 1997). Having considered Bolton's description as applied to this research work, teachers' perceptions can be referred to the attitudes, behavior, self-beliefs, views and the understanding that teachers hold toward the use of ICT in education. Teachers' perceptions explain the beliefs that teachers have about the relevance of integrating ICT into teaching and learning, and the perceived obstacles that are associated with using ICT in Education (Hutchison \& Reinking, 2011). According to Wang, (2002), the teacher's perception on the use of ICT can be explained as the way in which teachers' regard, understand, and interpret the use of technology in teaching and learning.

Teachers hold diverse perspective on the use of ICT in education. Teachers' perceptions are critical to the success or failure of ICT integration in education (Apeanti, 2014). For this reason, it is vital that researchers gather information about the apprehension teachers hold regarding the use of ICT in the classrooms. The decisions regarding whether and/or how to use ICT in education rests on the shoulders of the classroom or subject teachers. It was reported that for education sector to achieve fundamental changes from classroom teaching practices, there is 
a need to examine the beliefs teachers hold about the use of ICT in teaching and learning in the mathematics classroom (Hutchison \& Reinking, 2011). For instance, Gebremedhin and Fenta (2015) reported a significant relationship between the perceptions of teachers toward the use of ICT in teaching-learning process. It is motivated by several other factors in schools such as staff motivation, willingness to use ICTs and availability of resources (M. A. Gebremedhin \& Fenta, 2015). Furthermore, Gebremedhin and Fenta (2015) have assessed teachers' perception on integrating ICT in Teaching-Learning process in a study conducted at Adwa College in Ethiopia. The study found teachers confronted with the unavailability of ICT resources for teaching and learning. The findings imply that most teachers in the college have not used ICT in their course teaching. Mac Callum and Jeffrey (2014) reported that the adoption of innovative technology in teaching and learning is based on measuring teachers' beliefs and attitudes to the technologies. Hlasna et al.(2017) pointed out that teachers at the primary school level, who use ICT in teaching, need adequate training. This training, according to the researchers, would improve teaching output through effective use of ICT. Based on the research conducted by Hlasna et al.(2017), they concluded that teachers who have had methodological training in the use of ICT in teaching quest to use ICT in teaching, while the opposite is reluctant to use ICT in teaching. This goes to underpin the relevance of providing ICT training to teachers.

Ghavifekr et al.(2016) found significant challenges associated with the use of ICT tools in teaching and learning. With this finding, the implementation of ICT in teaching and learning is faced with limited accessibility and poor network connection, limited technical support, limited time and lack of teachers' competency. With the intent of using ICT, Khokhar and Javaid (2016) stated that teachers are bedeviled with challenges such as ICT devices being restricted to classroom teaching. Equally, some teachers maintain that to use ICT in education, more time is needed for the instruction. It means that much instructional responsibility and skills must use the technological tools (Sim \& Theng, 2007). A challenge that teachers face when integrating ICT in education is that some schools have forbidden mobile phones, iPods. They claim that these gadgets interfere with their lessons (Kolog et al., 2018; Mura \& Diamantini, 2014). In the same vein, these challenges can further be stretched to the teachers' practice of spending much of their teaching hours online, mainly to play games, engaging on social media and watch movies or listen to music instead of searching for educational materials. Based on the views of Kizlik (2008), it is crucial that teachers teach their pupils to appropriate ICT capability before applying it in other subjects. Even though there is a strong relationship between ICT the subject and ICT in subjects, some teachers may find it a challenge 
to lay a foundation of ICT usage for their pupils if they (teachers) are not capacitated on the effective use of ICT. However, although the Ministry of Education, Nepal has developed and implemented numerous policies and programs with a strong focus on ICTs Education, such as the National IT Policy(Communication, 2015; Government of Nepal Infromation Technology Higher Commission, 2010) 10th Plan (His Majesty's Government National Planning Commission, 2002), Three -Year Interim Plan (Government of Nepal National Planning Commission, 2007, 2010), School Sector Reform Plan (Government of Nepal Ministry of Education, 2009). Ministry of Education (2016) has implemented various interventions to achieve the goal of education in Nepal. Use of ICTs in education has been considered a strategy to reach the broader level objectives of education. The Government of Nepal, Ministry of Education, through the National Curriculum Framework (NCF), introduced ICT as a subject and ICT as a teaching tool in school education (Nepal, 2016). The application of the Master Plan for Information and Communication Technologies in Education(Government of Nepal Ministry of Education, 2013) has increased access to computers and the Internet in schools, increasing the use of ICT in schools' education. The recent National Education Plan is the School Sector Development Plan, (Ministry of Education, 2016) in schools to improve the use of ICT by teachers; it has not been usefully embraced in the teaching and learning process in many schools across the country. Only a few teachers are using ICTs as teaching and learning tools. Indeed, the use of ICT is still a growing phenomenon in the education sector. It is not amazing that, although it is a leading exercise, its integration within the educational sector is faced with numerous challenges outweigh the benefits (Bingimlas, 2009). Gebremedhin and Fenta (2015) have admitted that ICT integration into education is fraught with numerous challenges that have bedeviled its effective integration into education. They also identified the challenges such as shortage of resources or technological tools, lack of technical support, poor ICT preparation for teachers and lack of encouragement for teachers, which may have negative implications on the teachers' perceptions toward the use of ICT in teaching and learning. Thus, they remarked that teachers' perception that teaching and learning would improve with ICT integration provided the challenges above are eliminated or minimized.

Therefore, this study should generate information on the perceptions and challenges of using ICT tools into teaching and learning processes of mathematics classrooms in the schools of Kathmandu, Nepal. With the changes in modern technology, learners need up-to-date knowledge to help them to be adapted to the changing world. Such knowledge can improve communication and skills in the 21 st century through e-commerce and self-employment in the ICT sector. Analyzing the 
above studies some questions arise in the mind of the researcher: -

- What are the perceptions of using ICT tools in the mathematics classroom among school teachers?

- What are the challenges of using ICT tools in the mathematics classroom among school teachers?

- Does the gender difference exist in the perceptions and challenges of using ICT tools in the mathematics classroom?

The researcher has tried out to address of the above questions. Therefore, this study is attempted to know "Teachers' Perception and Challenges of Using ICT in Teaching Mathematics.

\section{Objective of the Study}

This study is conducted to analyze teachers' perception and challenges of using ICT in teaching mathematics of Kathmandu district in Nepal. Therefore, the main objectives of this study are:

- To identify the teachers' perceptions of using ICT tools in teaching and learning activities in mathematics classrooms.

- To determine the challenges of using ICT tools in teaching and learning activities in mathematics classroom.

- To compare the perceptions and challenges of using ICT in teaching and learning activities at mathematics classroom by gender.

\section{Procedure of the Study}

This study was designed to find out teachers' perception and challenges of using ICT in teaching mathematics at the Kathmandu district. This study applied a quantitative descriptive survey method of educational research to complete the study. The descriptive survey method has been one of the most popular and most widely used research methods in mathematics education.

\section{Population}

The population is the set of the people or objects the researcher wants to generalize the results of the research (Borg \& Gall, 1989). The population of this study constituted all the teachers who were teaching compulsory mathematics at grade $\mathrm{X}$ of Government schools of Kathmandu district in the academic year 2019-2020.

\section{Sample}

The representative part or subset of the population is called a sample (Chawla \& Sondhi, 2018). According to the Education Development and Coordinate Unite, Kathmandu district, there were a total 261 mathematics teachers teaching compulsory mathematics at grade X. From the total population of 261 teachers, 158 
were selected by using a simple random sampling method as a sample. Of those, 102 were male and 65 were female teachers for the study. The Slovin's formula of finding sample size from the total population is: $\mathrm{n}=\mathrm{N} /\left(1+\mathrm{Ne}^{2}\right)$, where $\mathrm{n}=$ sample size, $\mathrm{N}=$ Total population, $\mathrm{e}=$ an error $(0.05)$, and the level of significance is $5 \%$ (Thomas, 2013, p. 20).

\section{Instrument}

The instrument for the study was developed structural questionnaire by the researcher. This structural questionnaire consisted of 19 items within two sections, where the section " $\mathrm{A}$ " contained 10 perceptions items and the section " $\mathrm{B}$ " contained 9 challenges items respectively of using ICT in teaching mathematics which was tested among teachers. Each item was scored on a 5-point Likert scale ranging from: 5= Strongly Agree, $4=$ Agree, $3=$ Neutral, $2=$ Disagree and $1=$ Strongly Disagree. The instrument was pilot tested which involved 15 teachers outside the sample study. The Cronbach alpha was used to determine the reliability co-efficient, which yielded 0.84 .

\section{Data Collection Procedure}

First, the researcher visited the sample schools and got permission from the relevant authorities to undertake research and informed to the sample teachers. The mission of the researcher was clearly explained: the exercise was only for academic purpose and that confidence was assured to motivate them to give their perception and challenges of using ICT in teaching mathematics without reservation. After that, the questionnaire was distributed by the researcher to 158 sample teachers and they were allowed enough time to complete the questionnaire. After that, the researcher collected the completed questionnaire for the data analysis.

\section{Data Analysis Procedure}

The data from the questionnaire of teachers' perception and challenges of using ICT in teaching mathematics in each item were numeracy coded and entered into SPSS-25 version database. Descriptive analysis (means and standard deviation) was used to describe each item in the following rule: (a) Decision rule $=$ Multiple option/ Number of Item, where multiple options are weighted as follows:

S.A. $=5$, A. $=4, \mathrm{~N} .=3, \mathrm{D} .=2, \mathrm{~S} . \mathrm{D} .=1$, Therefore, $5+4+3+2+1=15 / 5=3$

\section{Thus, for perception:}

- If $3<$ the mean value of each item, then positive perception

- If the mean value of each item $<3$, then the negative perception

For Challenges:

- If $3<$ the mean value of item, then there are challenges items. 
- If the mean value of each item $<3$, then there is no challenges item (Otemuyiwa \& Attah, 2020). Also, the independent sample t-test was used for the analysis of the third objective at a 0.05 level of significance.

\section{Results and Discussion}

\section{Table 1}

Teachers' Perception of Using ICT in Teaching Mathematics

\begin{tabular}{|c|c|c|c|}
\hline Items & Statements & Mean & S.D. \\
\hline 1 & $\begin{array}{l}\text { In my view, using ICTs are more powerful tools of } \\
\text { teaching than without the use of ICTs. }\end{array}$ & 3.11 & 0.93 \\
\hline 2 & $\begin{array}{l}\text { I know that, using ICTs enhances my learners' critical } \\
\text { thinking. }\end{array}$ & 3.03 & 0.95 \\
\hline 3 & $\begin{array}{l}\text { ICTs can be used as advanced instructional tools in } \\
\text { teaching mathematics to my students. }\end{array}$ & 3.53 & 0.92 \\
\hline 4 & $\begin{array}{l}\text { In my view, ICTs can replace teachers' role in teaching } \\
\text { mathematics. }\end{array}$ & 2.21 & 0.79 \\
\hline 5 & $\begin{array}{l}\text { As far as I know, ICTs can be used to effectively } \\
\text { manipulate instructional contents and materials. }\end{array}$ & 3.20 & 0.80 \\
\hline 6 & $\begin{array}{l}\text { Using ICTs enhance collaborative learning among } \\
\text { learners and teachers. }\end{array}$ & 3.54 & 0.83 \\
\hline 7 & $\begin{array}{l}\text { Using ICTs enhance collaborative learning among } \\
\text { learners and teachers. }\end{array}$ & 3.54 & 0.83 \\
\hline 8 & Using ICTs help to ensure quality education. & 3.03 & 0.80 \\
\hline 9 & $\begin{array}{l}\text { The lack of ICTs makes it difficult for teachers to keep up } \\
\text { with the current trends in Mathematics education. }\end{array}$ & 3.29 & 0.82 \\
\hline \multirow[t]{2}{*}{10} & $\begin{array}{l}\text { In my view, the use of ICTs in teaching and learning } \\
\text { mathematics is a time- consuming process. }\end{array}$ & 3.16 & 0.82 \\
\hline & Overall Mean & 3.16 & 0.86 \\
\hline
\end{tabular}

The analysis of the information mentioned in table 1 was the perception about using ICT in mathematics classroom. Majority of the items were found positive perception that have using ICTs are more powerful tools of teaching than without the use of ICTs $(\mathrm{M}=3.11, \mathrm{SD}=0.93)$, using ICTs enhance my learners' critical thinking $(\mathrm{M}=3.03, \mathrm{SD}=0.95)$, ICTs can be used as advanced instructional tools $(\mathrm{M}=3.53$, 
$\mathrm{SD}=0.92)$, ICTs can be used to effectively manipulate instructional contents and materials $(\mathrm{M}=3.20, \mathrm{SD}=0.80)$, Using ICTs enhance collaborative learning among learners and teachers $(\mathrm{M}=3.54, \mathrm{SD}=0.83)$, ICTs are more effective for teaching and learning than books and other printed materials $(\mathrm{M}=3.27, \mathrm{SD}=0.92)$, Using ICTs helps to ensure quality education $(\mathrm{M}=3.03, \mathrm{SD}=0.80)$, Lack of ICTs makes it difficult for teacher to keep up with the current trends in Mathematics education $(\mathrm{M}=3.29, \mathrm{SD}=0.82)$, use of ICTs in teaching and learning Mathematics a time consuming process $(\mathrm{M}=3.16, \mathrm{SD}=0.82)$ but, ICTs can replace teachers' role in teaching Mathematics $(\mathrm{M}=2.21, \mathrm{SD}=0.79)$ has negative perception only. The mean level of the perception statement was in between 2.21 to 3.54. While overall mean is 3.16 and standard deviation is 0.86 which indicates the positive perception.

The overall results presented in Table 1 shows that the secondary school teachers of the Kathmandu district of Nepal hold positive perceptions toward the use of ICT in teaching and learning in mathematics classes. The implication of this finding is that the teacher admires the relevant use of ICT in teaching and learning activities in the mathematics classroom in the 21 st century. The result of this study is consistent with the results of Kayisire and Wei (2016), Igbo and Imo (2017), Dutton and Meyer (2009), Gebremedhin and Fenta (2015), Adam (2014), Yunus (2014), and Kreijns (2013) who reported a positive perception of teachers toward the use of ICT in the teaching-learning process. This implies that the positive perceptions of the use of ICT in mathematics classrooms were highly relevant in their classrooms. Thus, the positive perception of school teachers was sensitive to the use of new ICTs to improve and facilitate their teaching-learning activities in mathematics classes. Also, teachers' motivation is a key and determining factor for using ICT in the classroom. Therefore, the government of Nepal through the Ministry of Education should motivate teachers toward enrichment and continuous positive perception on the use of ICT in teaching and learning in mathematics classrooms. Hassanzadeh et al.(2012) supported that teacher motivation is integral to improving teachers' positive attitudes toward the use of ICT in teaching and learning. With these findings, teachers' motivation on the use of ICT can be boosted through various interventions such as courses, programs, conferences, seminars, events, and workshops, from fellow teachers or colleagues, through experience and experimentation, personal research, professional networks, and associations or continuous professional development (UNESCO, 2003). 


\section{Table 2}

Teachers' Challenges of Using ICT in Teaching Mathematics

\begin{tabular}{|c|c|c|c|}
\hline Items & Statements & Mean & S. D \\
\hline 1 & $\begin{array}{l}\text { I have a lack of knowledge about using ICTs in teaching } \\
\text { Mathematics. }\end{array}$ & 3.41 & 0.93 \\
\hline 2 & $\begin{array}{l}\text { I know that many forms of the ICT tools and techniques } \\
\text { at schools are accessible to use in teaching mathematics. }\end{array}$ & 3.20 & 0.89 \\
\hline 3 & $\begin{array}{l}\text { I have the lack of technical support from school } \\
\text { administration. }\end{array}$ & 3.57 & 0.76 \\
\hline 4 & The lack of genuine ICT Software at school. & 3.68 & 0.85 \\
\hline 5 & $\begin{array}{l}\text { In my view, unstable and unreliable internet connection } \\
\text { at school and home. }\end{array}$ & 3.21 & 1.01 \\
\hline 6 & $\begin{array}{l}\text { I have limited time of using ICT in the classroom } \\
\text { teaching. }\end{array}$ & 3.55 & 0.87 \\
\hline 7 & $\begin{array}{l}\text { The lack of confidence of using ICT in the classroom } \\
\text { teaching. }\end{array}$ & 3.43 & 0.82 \\
\hline 8 & $\begin{array}{l}\text { I have enough experience and training of using ICT in } \\
\text { the classroom teaching. }\end{array}$ & 3.52 & 0.78 \\
\hline 9 & $\begin{array}{l}\text { The lack of interest in the teacher of using ICT in the } \\
\text { classroom. }\end{array}$ & 3.13 & 0.92 \\
\hline & Overall Mean & 3.41 & $\mathbf{0 . 8 7}$ \\
\hline
\end{tabular}

The analysis of the information mentioned in table 2 was the challenges about using ICT in mathematics classrooms. It was found that the means of lack of knowledge $(M=3.41, S D=0.93)$, accessible of ICT tools and techniques at schools $(M=3.20, S D=0.89)$, the lack of technical support from school administration $(M$ $=3.57, S D=0.76)$, lack of genuine ICTs Software at school $(M=3.68, S D=0.85)$, unstable and unreliable internet connection $(M=3.21, S D=1.01)$, limited time of using ICT in the classroom teaching $(M=3.55, S D=0.87)$, Lack of confidence of using ICT $(M=3.43, S D=0.82)$, enough experience and training of using ICT $(M=3.52, S D=0.78)$ and lack of interest in teacher of using ICT in classroom $(M$ $=3.13, S D=0.92)$ were greater than 3.00. Also, the mean level of the statement was in between 3.13 to 3.68 , while overall mean is 3.41 , which is the high level of challenges.

The overall results as presented in Table 2 in this study have nine challenges 
of the secondary school teachers of Kathmandu district of Nepal toward the use of ICT in teaching mathematics classes, which are: (1) Lack of knowledge, (2) Accessible to ICT tools and techniques, (3) Technical support, (4) Lack of ICT software's, (5) Lack of internet connection, (6) Limited time, (7) Confidence, (8) Training, and (9) Interest of teachers. These results are consistent with the other recent studies conducted by Gebremedhin and Fenta (2015), Ghavifekr et al. (2016), Khokhar and Javaid (2016), Goktas et al. (2009), Tondeur et al. (2008), Sife et al. (2007), and Jung (2005) reported that the technical support, lack of motivation, ICT device, lack of time, lack of skills, lack of in-service training, lack of appropriate software and materials and lack of hardware are the main challenges for using ICT in teaching, and learning in the mathematics classroom. Many other studies such as those of Asongu and Roux (2017), Bornman (2015), and Tabira and Otieno (2017) reported that the lack of training, limited time, accessible of ICT tools are the challenges to the teachers in using it in the classroom teaching.

To solve these challenges faced by the teachers suggested that the government should : (1) train them to gain the required knowledge, (2) support the teachers to have their own laptop and other required technological tools and software, (3) provide the required infrastructures, (4) increasing the teachers' motivation, (5) increase the salary of the teachers, (6) make the plan for the collaboration between stakeholders, educational planner, ICT exports to use the ICT effectively, and (7) allocate the markets for the promotion of the teachers who use the ICT tools in teaching-learning activities at the classrooms.

\section{Table 3}

Comparison of Mean Scores of the Perception Gender in Using ICT

\begin{tabular}{lcccccc}
\hline Perception of using & Gender & $\mathbf{N}$ & Mean & SD & t-value & p-value \\
\cline { 2 - 7 } ICT in classroom & Male & 102 & 31.58 & 2.86 & 0.51 & 0.105 \\
& Female & 56 & 31.34 & 2.79 & & \\
\hline
\end{tabular}

The results drawn from the independent t-test means in table 3 show that the perception of using ICT in the mathematics classroom of male $(M=31.58, S D$ $=2.86$ ) is higher than the perception of using ICT in the mathematics classroom of female $(M=31.34, S D=2.79)$. Since the calculated $t$-value was 0.51 , which is less than the tabulated value to $0.05,156=1.96$. Hence, it is concluded that the means of the perception of male teachers' in using ICT in the mathematics classroom is higher than female teachers' but insignificant difference at 0.05 level. It's consistent with the results concluded by Emeka and Fomsi (2017) Yuan and Lee (2012), and Gebhardt et al. (2019). 


\section{Table 4}

Comparison of Mean Scores of the Challenges of Gender in Using ICT

\begin{tabular}{lcccccc}
\hline Challenges of Using & Gender & N & Mean & S.D. & t-value & p-value \\
\cline { 2 - 7 } ICT in classroom & Male & 102 & 30.84 & 2.45 & 0.91 & 0.156 \\
& Female & 56 & 30.45 & 2.90 & & \\
\hline
\end{tabular}

The results drawn information from the independent t-test means in table 4, show that the challenges of using ICT in the mathematics classroom of male ( $M=$ $30.84, S D=2.45$ ) are higher than the challenges of using ICT in the mathematics classroom of female $(M=30.45, S D=2.90)$. Since the calculated $t$-value was 0.91 which is less than the tabulated value to $0.05,156=1.96$. Hence, it is concluded that the means of the challenges of male teachers' in using ICT in the mathematics classroom is higher than female teachers' but insignificant different at 0.05 level. It's consistent with the results concluded by Dhital (2018).

\section{Conclusion}

This study was concerned to identify the teachers' perception and challenges of using ICT in mathematics classrooms at secondary level of the Government schools in the Kathmandu district. Referring to the result and discussion that have been detailed above, the researcher found that teachers' perception of using ICTs in teaching- learning activities in the mathematics classroom was positive; nonetheless, ICT cannot replace the teacher because it cannot play the living role model that the teachers can offer the student. However, there were some challenges encountered by the teachers such as lack of knowledge, low confidence, lack of enough experience, inadequate training, lack of interest as well as accessible of ICT tools, the lack of technical support, lack of genuine ICTs Software, unstable and unreliable internet connection at the schools were also the main challenges in using ICT tools in the teaching learning process at mathematics classroom in school level. Thus, it is logical to say that the use of ICT is necessary and an effective supplementary material in the teaching-learning process of the mathematics classroom. Generally, teachers did not use ICT in the classroom to radically change their pedagogical practices, so that teachers should learn more to improve their knowledge and skills in ICT. A solution could be to provide proper training and enhance technological skills through ICT institute for school teachers and government should make the proper action plan to minimize the challenges on use of ICT in the mathematics classroom.

This research is limited to the study on perception of teachers on the use of ICTs in teaching mathematics in the classroom of grade $\mathrm{X}$ as well as the challenges 
encountered by them. Future researches could move beyond and look into other relevant issues like management strategies and policies to reduce the challenges faced by the teachers in using ICT in the mathematics classroom. If the challenges faced by the teachers can be minimized or solved, it is sure to enhance our students' learning outcome.

\section{Reference}

Adam, A. S. (2014). Maldivian teacher educators' cultural embodiment and the shaping of ICT habitus in their pedagogical practices. Waikato Journal of Education, 19(1).

Apeanti, W. (2014). Prospective mathematics teachers' perception about ICT integration in mathematics instruction in Ghana. Global Educational Research JouApeanti, 10(2), 174-184. https://rb.gy/brszhw

Asongu, S. A., \& Roux, S. Le. (2017). Enhancing ICT for inclusive human development in Sub-Saharan Africa. Technological Forecasting and Social Change, 118, 44-54. https://doi.org/https://doi.org/10.1016/j. techfore.2017.01.026

Balanskat, A., Blamire, R., \& Kefala, S. (2006). A Review of studies of ICT impact on schools in Europe (First). European School Net.

Bingimlas, K. A. (2009). Barriers to the successful integration and learning environments: A review of the literature. Eurasia Journal of Mathematics, Science and Technology Education, 5(3), 235-245. https://doi.org/10.12973/ ejmste $/ 75275$

Borg, W. R., \& Gall, M. D. (1989). Educational research: An introduction (5th (ed.)). New York: Longman. https://psycnet.apa.org/record/1996-97171-000

Bornman, E. (2015). Information society and digital divide in South Africa: Results of longitudinal surveys. Information, Communication \& Society, 19(2), 264278. https://doi.org/https://doi.org/10.1080/1369118X.2015.1065285

Boulton, M. J. (1997). Teachers' views on bullying: Definitions, attitudes and ability to cope. British Journal of Educational Psychology, 67(2), 223-233. https://doi. org/10.1111/j.2044-8279.1997.tb01239.x

Bransford, J., Brown, A. L., \& Cocking, R. R. (2000). How people learn: Brain, mind, experience, and school (2nd ed.). Washington, D.C.: National Academy Press.

Chawla, D., \& Sondhi, N. (2018). Research methodology concept and cases (2nd ed.). New Delhi, India: Vikas Publishing House Pvt Ltd. 
Communication, M. (2015). National information and communication technology policy, 2015. http://www.youthmetro.org/uploads/4/7/6/5/47654969/ict_policy_ nepal.pdf

Dawes, L. (2001). What stops teachers using new technology? In M. Leask (Ed.), Issues in Teaching using ICT. London: Routledge.

Dhital, H. (2018). Opportunities and challenges to use ICT in government school education of Nepal. International Journal of Innovative Research in Computer and Communication Engineering, 6(4). www.ijircce.com

Dutton, W. H., \& Meyer, E. T. (2009). Experience with new tools and infrastructures of research: An exploratory study of distance from, and attitudes toward, e-research. Prometheus: Critical Studies in Innovation, 27(3), 223-238. https:// doi.org/10.1080/08109020903127802

Emeka, O. S., \& Fomsi, E. F. (2017). Gender differences in the use of ICT among teachers in model primary schools in rivers state, Nigeria. British Journal of Education, 5(4), 88-94.

Gebhardt, E., Thomson, S., Ainley, J., \& Hillman, K. (2019). Gender differences in computer and information literacy. In Teacher gender and ICT (pp. 53-86). https://doi.org/https://doi.org/10.1007/978-3-030-26203-7_5

Gebremedhin, Matha Alter, \& Fenta, A. A. (2015). Assessing teachers' perception on integrating ICT in teaching-learning process: The case of adwa college. Journal of Education and Practice, 6(4), 114-124. https://files.eric.ed.gov/fulltext/ EJ1083759.pdf

Ghavifekr, S., Kunjappan, T., Ramasamy, L., \& Anthony, A. (2016). Teaching and learning with ICT Tools: Issues and challenges from teachers' perceptions. Malaysian Online Journal of Educational Technology, 4(2), 38-57. https://eric. ed.gov/?id=EJ1096028

Ghavifekr, Simin, Kunjappan, T., Ramasamy, L., \& Anthony, A. (2016). Teaching and learning with ICT tools: Issues and challenges from teachers' perceptions. Malaysian Online Journal of Educational Technology, 4(2), 38-57. https://files. eric.ed.gov/fulltext/EJ1096028.pdf

Goktas, Y., Yildirim, S., \& Yildirim, Z. (2009). Main barriers and possible enablers of ICTs integration into pre-service teacher education programs. Educational Technology \& Society, 12(1), 193-204. https://www.learntechlib.org/p/75176/.

Government of Nepal Infromation Technology Higher Commission. (2010). Information and Technology Policy 2010. https://www.nitc.gov.np/assets/img/ fileSystem/download/20-11-09-012650-IT_Policy_2067.pdf 
Government of Nepal Ministry of Education. (2009). School sector reform plan 2009-2015 (Issue August 2009). http://www.moe.gov.np/assets/uploads/files/ SSRP_English.pdf School reform 2009-15

Government of Nepal Ministry of Education. (2013). Information and communication technology (ICT) in education master plan 2013-2017 (Issue March 2013). https://www.moe.gov.np/assets/uploads/files/ICT_MP_2013_ (Final)_.pdf

Government of Nepal National Planning Commission. (2007). Three year interim plan 2007-2010 (Issue December 2007). https://www.npc.gov.np/images/ category/11tyip_eng.pdf

Government of Nepal National Planning Commission. (2010). Three year plan approach paper 2010/11 - 2012/13. https://dokumen.tips/download/link/nepal3y-plan-2010-2013

Hassanzadeh, V., Gholami, R., Allahyar, N., \& Noordin, N. (2012). Motivation and personality traits of TESL postgraduate students towards the use of information and communications technology (ICT) in second language teaching. English Language Teaching, 5(4), 74-86. www.ccsenet.org/elt

His Majesty's Government National Planning Commission. (2002). Tenth plan 20022007. https://www.npc.gov.np/images/category/10th_eng.pdf

Hlasna, P., Klímová, B., \& Poulova, P. (2017). Use of information and communication technologies in primary education: A case study of the czech republic. International Electronic Journal of Elementary Education, 9(3), 681692. https://files.eric.ed.gov/fulltext/EJ1134184.pdf

Hutchison, A., \& Reinking, D. (2011). Teachers' perceptions of integrating information and communication technologies into literacy instruction. A National Survey in the United States, Reading Research Quarterly, 46(4), 312-333.

Igbo, H. U., \& Imo, N. T. (2017). Electronic information resource sharing among university libraries in southern Nigeria:Opportunities and challenges. African Journal of Library Archives and Information Science, 27(1), 77-91. https:// www.ajol.info/index.php/ajlais/article/view/164660

Jung, I. (2005). ICT-pedagogy integration in teacher training: Application cases worldwide. Educational Technology \& Society, 8(2), 94-101. https://www. ds.unipi.gr/et\&s/journals/8_2/8.pdf

Kayisire, D., \& Wei, J. (2016). ICT adoption and usage in Africa:Towards an efficiencey assessment. Information Technology for Development, 22(4), 630653. https://doi.org/https://doi.org/10.1080/02681102.2015.1081862 
Khokhar, A. J., \& Javaid, S. (2016). Students and teachers perceptions of ICT use in classroom: Pakistani classrooms. The International Academic Forum, 1-11. https://iafor.org/

Kizlik, B. (2008). Pedagogy and practice. Teaching and Learning in Secondary Schools, 6(2), 132-140.

Kolog, E. A., Tweneboah, S. N. A., Devine, S. N. O., \& Adusei, A. K. (2018). Investigating the use of mobile devices in schools: A case of the ghanaian senior high schools. In mobile technologies and socio-economic development in emerging nations, 7(3), 81-108.

Kreijns, K. (2013). What stimulates teachers to integrate ICT in their pedagogical practices? The use of digital learning materials in education. Computers in Human Behavior, 29(1), 217-225.

Lefebvre, S., Deaudelin, D., \& Loiselle, J. (2006). ICT implementation stages of srimary school teachers: The practices and conception of teaching and learning. Paper Presented at the Australian Association for Research in Education National Conference, Adelaide, Australia.

Mac Callum, K., \& Jeffrey, L. (2014). Factors impacting teachers' adoption of mobile learning. Journal of Information Technology Education, 13(2). http://www.jite. org/documents/Vol13/JITEv13ResearchP141-162MacCallum0455.pdf

Ministry of Education. (2016). School Sector Plan 2016-2023.

Mura, G., \& Diamantini, D. (2014). The use and perception of ICT among educators: the Italian case. Procedia-Social and Behavioral Sciences, 141, 1228-1233. https://doi.org/DOI: 10.1016/j.sbspro.2014.05.211

Nepal, T. V. (2016). A Study on the use of ICT and its sustainability in school education. department of education sanothimi, bhaktapure, Nepal.

Otemuyiwa, B. I., \& Attah, O. J. (2020). Teachers' perception on the use of information and communication technology for instructionaal delivery. International Journal of Innovative Technology Integration in Education (IJITIE), 4(2), 25-33. https://www.ijitie.aitie.org.ng/index.php/ijitie/article/ view/157/86

Sife, A., Lwoga, E., \& Sanga, C. (2007). New technologies for teaching and learning: Challenges for higher learning institutions in developing countries. International Journal of Education and Development Using ICT, 3(2), 57-67. https://www.learntechlib.org/p/42360/. 
Sim, J. C., \& Theng, L. B. (2007). Teachers'perceptions of the use of ICT as an instructional tool in mathematics and science. https://www.semanticscholar.org

Tabira, Y., \& Otieno, F. X. (2017). Integration and implementation of sustainable ICT-based education in developing countries: low-cost, en masse methodology in Kenya. Sustainability Science, 12(2), 221-234.

Thomas, P. R. (2013). Sample size determination and power. John Wiley \& Sons, Inc. https://www.libgen.is/book/index. php?md5=76103AF97E370A2858DC169714C2CF02

Tondeur, J., Keer, H. Van, Braak, J. Van, \& Valcke, M. (2008). ICT integration in the classroom: Challenging the potential of a school policy. Computers \& Education, 51, 212-223. www.sciencedirect.com

UNESCO. (2003). Developing and using indicators of ICT use in education. https:// unesdoc.unesco.org/ark:/48223/pf0000131124

Wang, Y.-M. (2002). When technology meets beliefs preservice teachers' perception of the teacher's role in the classroom with computers. Journal of Research on Technology in Education, 35(1), 150-161. https://doi.org/10.1080/15391523.20 02.10782376

Yuan, Y., \& Lee, C.-Y. (2012). Elementary school teachers' perceptions toward ICT: The case of using magic board for teaching mathematics. The Turkish Online Journal of Educational Technology, 11(4). https://files.eric.ed.gov/fulltext/ EJ989260.pdf

Yunus, M. (2014). Future of ICT as a pedagogical tool in ESL teaching and learning. Research Journal of Applied Sciences, Engineering and Technology, 7(4), 764 770. 